\title{
The impact of globalization on the selected aspects of the regional marketing
}

\author{
Renáta Bundzíková ${ }^{1, *}$, and Denisa Jánošová ${ }^{1}$ \\ ${ }^{1}$ University of Ss. Cyril and Methodius, Faculty of Mass Media Communication, Department of \\ Marketing Communication, Nám. J. Herdu 2, 91701 Trnava, Slovakia
}

\begin{abstract}
.
Research background: In today's globalized world, tourism is considered to be one of the fastest-growing sectors in the field of service. Tourism continuously adapts to various new activities, trends, markets and technologies. Tourism is affected by several factors - mainly globalization trends, consumers and economic gain. Regional development experts consider tourism as one of the tools that can support the quality of the environment and thus protect existing aboriginal cultures. Tourism itself is considered to be a global phenomenon currently being studied by experts from several scientific disciplines. Globalization plays an important role when traveling to world tourism destinations. With globalization coming to the forefront, people began to realize how small the world is. However, high demands on the environment, the constant use of non-renewable resources, the destruction of cultural values of society and other adverse effects of tourism are not signs of sustainability. Various international organizations are trying to solve these issues by creating specific programs aimed at promoting sustainable tourism.

Purpose of the article: The main goal of our paper is to identify and analyse indicators of sustainable tourism, specifically in the Trenčín region in Slovakia.

Methods: The main goal of the paper is to critically evaluate the results of the analysis and formulate recommendations for implementation in practice in the Trenčín region based on the available data.

Findings \& Value added: We consider regional development and its connected, sustainable tourism to be an essential topic. It is necessary for regions to become active in their future development, not only economically and socially, but also ecologically.
\end{abstract}

Keywords: globalization; circular economy; regional development; marketing mix; tourism

JEL Classification: $M 31 ; L 83 ; R 11$

*Corresponding author: r.bundzikova@gmail.com 


\section{Introduction}

Tourism plays an essential role in the economy of the European Union, as well as the Slovak Republic. Its main contribution is, in particular, the support of economic development and employment in a particular area. We must also be aware of its other side. Tourism is also responsible for the high percentage of exceeding the environmental limits in the selected destination, as well as the social and economic ones [1]. Mostly, it is the constant depletion of non-renewable resources in destinations, the destruction of their cultural values and various other phenomena that are not connected at all to sustainability in destinations. International organizations such as the UNWTO, the UN and the EU try to promote the issues and related solutions to sustainable tourism. The continually increasing demand from tourists, stimulating growth in the tourism sector, and, on the other hand, the limited number of natural, social and economic resources in destinations could be solved by the concept of sustainable tourism. Maintaining cultural values and a way of life that seeks to minimize environmental damage is crucial for keeping sustainable tourism. In connection with the sustainable development of tourism in the region, we use indicators [4, $2,3]$. If the region uses the indicators, it brings a strategic advantage for the area in connection with its sustainability in tourism. Indicators are mostly used to find answers to questions about the natural resources and environmental conditions of a tourist destination, economic sustainability, cultural goods and values of society, organizations and management within the tourism sector [3]. We have divided this article into a theoretical and analytical part. In the theoretical part, we deal with globalization, sustainability, regional development and related - tourism. In the analytical part, we explain indicators of sustainable tourism for the Trenčín region. In conclusion, we focus on providing recommendations within the indicators that could help improve the current situation in the Trenčín region.

\subsection{Globalization and its impacts}

At present, globalization is considered to be one of the most important, but also the latest phenomena, which does not relate only to politics [4-6]. The globalization of the world caused the interconnection of several areas, such as communication, the economy, culture and the environment. Therefore we can define globalization as an internationalized process that aims to unite worldwide. Globalization is a process with influence often classified as contradictory, especially in expert literature. At the same time, globalization is a term often used, especially in connection with socio-economic and political issues, technological development and changes in people's lifestyles. People realize that information, goods or knowledge move faster, better and, most importantly, cheaper than in the past. Globalization contributes to the redistribution of power in different countries, leading to the benefit of supranational societies of different natures. By globalization, we mean the gradual interconnection of economic and financial markets, as well as the growth of institutions beyond the borders of a particular country [7, 8]. The various individuals and actors in a particular area become one interconnected, complete factor in world politics. It may lead to a new division of labour within a renewed political and economic order that includes a new structure or regime for the world economic system [9]. Globalization also contributes to the creation of a cosmopolitan culture at various stages of operation, where the main determinants include internationality, universality, modernization and liberalism. The continually increasing interdependence between markets, policies or communities causes the current international system to play a crucial role. We could conceptually classify views on globalization into various schools of thought, which we could further divide into other parts according to the types of globalization. Under the term school of 
thought, we understand opinions or directions of thinking, which define mainly economic, legal, military, cultural and ecological globalization or typologically combined globalization from a particular point of view [10]. In the professional literature, there are views on globalization from an economic point of view, but its social impacts are taken into account less. From a social point of view, globalization is seen as a process that unites the whole world. However, one has to realize that this connection, interconnection and, ultimately, globalization also has its contradictory character. Globalization is a human creation, a creation of our thinking, actions and motivations. Widening the possibilities of expansion and the emergence of entirely new possibilities has connected humanity worldwide. We can perceive this connection in every area of our perception.

\subsection{Regional development}

It is challenging to define the term of development. This concept thus becomes a vague concept, which we can explain concerning specific value attitudes. We should pay attention to the fact that development itself cannot be equated with economic growth [11]. However, it is also true that the fundamental element of development is precisely economic growth. Economic growth can be explained as an increase in the total volume of GDP in a given period compared to the previous period. If we look at development considering the area, we recognize the development of the territory, and therefore regional development. In the literature, we can find several definitions that deal with terms of regional development. However, relatively all technical definitions agree that regional development is expressed by a systematic process of positive change, which is further based on the individual capacity of the regions [12]. By these abilities, the authors mean the use of resources and benefits for the overall benefit of the region primarily. We can perceive the development of the region in several ways. Perhaps the most frequently discussed is the economic and social development of the region. The economic development of the region brings along one fundamental fact, and that is the deterioration of the relative position of one group of inhabitants compared to another [1]. It leads to a certain degree of social inequality, such as income inequalities, fluctuating unemployment rates, etc.). Economic development can mean various inconveniences for society, and it is therefore right that social policy, as well as links with economic and environmental policy, is addressed as the hot topics parallel. Social development in the region focuses mainly on eliminating inequalities in the area of poverty and employment, which is associated with reducing unemployment in the region. Social and economic development is, therefore, intertwined, as economic development is a prerequisite for social development [10]. Considering the above, we can say that for the increasingly frequent socio-economic development of regions - there is a reason. Regional development should undoubtedly contribute to the territorial development of the particular area. The legislation of the Slovak Republic includes several laws that address this issue. It is, for example, Act no. 50/1976 Coll. on spatial planning and building regulations. According to it, territorial development satisfies the basic living needs of the people in the country, especially in a sustainable way, thanks to which its diversity is not reduced. Sustainability is a topical issue in both regional and territorial development. Act no. $17 / 1992$ Coll. mentions the environment as a development that also considers the benefit of future generations. The satisfaction of needs is preserved for current and future generations, by not violating the ecosystem and diversity of nature.

\subsubsection{Tourism}

Tourism is considered a complex global phenomenon, being studied by scientists from different scientific disciplines. At the beginning of the research, the focus was not scientific 
systematics while distinguishing and naming phenomena, but rather its empirical description [13]. However, we should not be misled because, despite its interdisciplinary nature, tourism always deals with people and their satisfaction with various needs focused on other than their place of residence. Tourism and its complexity and difficulty results in the non-existent uniform, has valid or universal definition that should define this term. An interdisciplinary approach is considered to be the advantage of tourism. However, this approach cannot be understood as a universal knowledge within the subject matter. The dynamic development and diversity of tourism in the 20th century caused great interest in several scientific disciplines (management, psychology, political science, economics, geography, informatics, marketing, etc.). The interest in tourism has brought various researches, having one topic in common. Thus, we can define tourism as a socio-economic process taking place in space and time. Globalization has been one of the driving forces behind the development of mass tourism, and it is, therefore, important to address its three levels of the substance, which are [14]:

- spatial (geographical),

- time (in terms of historical development),

- interdisciplinary (synthetic essence of tourism).

Tourism is associated with the development of regions because it positively impacts its economic, social, cultural and environmental aspects. The fundamental pillar supporting development in the region is anthropogenic and natural potential. Given the mentioned potential that the region has, it can satisfy the needs, but also provoke a renewed need for tourism participants. The development of tourism in the region means positive effects for the economy, entrepreneurs, residents and visitors to the area $[2,15]$.

The task of sustainable tourism is to meet specific current needs without limiting the ability to meet the needs of the next generation. Sustainable tourism is based on several assumptions:

- Natural resources, crucial for the development of tourism, are used optimally.

- The socio-cultural authenticity of the host communities is respected. Also, the status of the population, traditions and cultural heritage is preserved.

- A viable long-term economy is assured, also in terms of socio-economic benefits [16].

In sustainable tourism, it is crucial to monitor it and implement corrective measures continuously. It is also essential to maintain a high standard in meeting the needs of tourists. Also, providing a meaningful experience for travellers and significantly raising their awareness of sustainable tourism.

\section{Methods}

The main goal of our paper is to identify and analyse indicators of sustainable tourism, specifically in the region of Trenčín in Slovakia. The main goal of the paper is to critically evaluate the results of the analysis and formulate recommendations for implementation in practice in the Trenčín region based on the available data. Before creating our set indicators for sustainable tourism, it was necessary to analyse those already existing. Using relevant publications, we were able to analyse all available studies and universal sets of indicators focused on sustainable tourism. A thorough analysis of sustainable tourism indicators was carried out in July 2020 by the authors of this article. We analysed the UNWTO study (Indicators of sustainable development for tourism destinations: A guidebook). In this study, the most common problem areas of destinations are listed together with the proposed indicators. It contains a total of 42 sustainable areas divided into 13 sections [17]. We further analysed the sets of indicators compiled through the OECD, which are part of the 
study Indicators for measuring competitiveness in tourism: A guidance document. The indicators presented in the study are intended to help measure the competitiveness and impact of tourism at the national level [18]. So far, the most modern set of indicators is the European Tourism Indicator System (ETIS): a set of tools for sustainable destination management developed by the European Commission in 2016. It is a management, information and monitoring tool designed primarily for tourist destinations [19]. As part of our analysis, we searched for and thoroughly examined the individual sets of indicators. We completed three foreign studies focused on sustainable tourism indicators, developed by international organizations, and subsequently analysed the nature and possibilities of our research facility - Trenčín region. Also, in the article, we used deduction, induction and synthesis. We have divided the proposed indicators for sustainable tourism in the Trenčín region into 3 main sections, in particular economic, socio-cultural and ecological. We consider these pillars to be leading ways in the field of regional development and related tourism. Each of the sections contains five indicators, which after analysing the available data and the object of research, we evaluate as suitable for future application in the improvement of sustainable tourism in the Trenčín region.

\section{Results and discussion}

The Trenčín region has profiled itself for some time by now as a suitable destination for various tourism activities and has a lot to offer visitors thanks to its natural and culturalhistorical potential [20]. One can find natural hot springs and mineral springs, a wide range of cultural, historical and natural monuments, castles, chateaux, museums, protected landscape areas, etc. In terms of its geographical location, it is easily accessible, both for domestic and foreign visitors. However, in order to keep the current level of traffic, it is necessary to take several steps related to innovations and the use of trends that have emerged in destination management in recent years. In order to increase traffic, it is essential to do more to make the region more visible and thus use its competitive advantage over other regions. Increasing traffic and number of visits is possible by increasing competitiveness through the high quality of services, the level and complexity of the products offered [20]. Within its competencies to ensure the development of tourism, the Trenčín region promotes the whole region as a destination and develops activities of various kinds, especially in improving transport accessibility, all types of public administration services, cooperation with partners within the established network such as cities, municipalities, museums, galleries, tourist information offices, tourism associations, secondary schools, universities, partner regions in the EU, professional associations, Slovak cycling club, spas, accommodation, catering, cultural and sports facilities, media with national, regional and local reach and airports in the territory of Trenčín region.

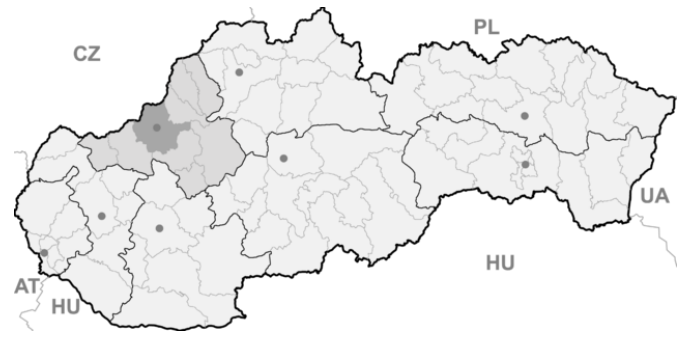

Fig. 1. Trenčín region on the map (northwest)

The indicators proposed by us in the Table 1 have a performance, qualitative, quantitative and capacity character. The indicators were adjusted to meet current needs and 
were able to be applied to the Trenčín region. For better clarity, we present the indicators in the table with a brief explanation of the benefits for the region. The indicators were designed for the economic, socio-cultural and environmental sections.

Table 1. Indicators of sustainable tourism in Trenčín region

\begin{tabular}{|c|c|}
\hline \multicolumn{2}{|r|}{ Economical section } \\
\hline Indicators & Benefits \\
\hline $\begin{array}{l}\text { Revenues from tourism as } \\
\% \text { of total revenues } \\
\text { generated by the destination }\end{array}$ & $\begin{array}{l}\text { Use to monitor the increase/decrease in tourist expenses and } \\
\text { to identify the type of tourists and attractions, bringing the } \\
\text { most significant economic benefit. }\end{array}$ \\
\hline $\begin{array}{l}\text { Share of tourism in regional } \\
\text { GDP }\end{array}$ & $\begin{array}{l}\text { Possible use of the indicator in examining the dependence } \\
\text { of the destination on tourism. }\end{array}$ \\
\hline $\begin{array}{l}\text { The capacity of } \\
\text { accommodation facilities }\end{array}$ & $\begin{array}{l}\text { The resulting values of the indicator are suitable for the } \\
\text { calculation of other indicators - e.g., the load of tourists in } \\
\text { the territory. }\end{array}$ \\
\hline Expenses of visitors & $\begin{array}{l}\text { The efficiency of tourism in the destination depends on the } \\
\text { level of tourist expenses. Monitoring its structure supports } \\
\text { the identification of potential risks or negative impacts. }\end{array}$ \\
\hline $\begin{array}{l}\text { Expenses to protect } \\
\text { monuments, nature and } \\
\text { landscape }\end{array}$ & $\begin{array}{c}\text { The indicator focuses on the expenditures of cities, country } \\
\text { and ministries, intended for the restoration and preservation } \\
\text { of cultural and historical heritage and the protection of the } \\
\text { environment. }\end{array}$ \\
\hline \multicolumn{2}{|r|}{ Social-cultural section } \\
\hline Indicators & Benefits \\
\hline $\begin{array}{l}\text { Satisfaction level of visitors } \\
\text { with the destination }\end{array}$ & $\begin{array}{l}\text { The indicator is crucial as it expresses whether tourists } \\
\text { return to the destination, recommend it or would never } \\
\text { come back again. The indicator is an indicator of the long- } \\
\text { term sustainability of the destination. }\end{array}$ \\
\hline
\end{tabular}




\begin{tabular}{|c|c|}
\hline $\begin{array}{l}\text { Attractiveness of the } \\
\text { destination compared to the } \\
\text { similar ones }\end{array}$ & $\begin{array}{l}\text { The indicator aims to assess the extent to which the tourists } \\
\text { are attracted by the unique attractions and whether they } \\
\text { provide them with overall satisfaction at a paid price. }\end{array}$ \\
\hline Irritation index & $\begin{array}{l}\text { The index measures the level of satisfaction of residents } \\
\text { with visitors to the destination. It is an empirically derived } \\
\text { indicator measuring the feelings of euphoria, apathy, disgust } \\
\text { and antagonistic attitude of residents. }\end{array}$ \\
\hline $\begin{array}{l}\text { Social benefits for the local } \\
\text { community }\end{array}$ & $\begin{array}{c}\text { Determining the degree of benefit or disadvantage of } \\
\text { tourism for the locals. }\end{array}$ \\
\hline Barrier-free tourism & $\begin{array}{l}\text { Sustainable tourism should be accessible to everybody, with } \\
\text { no exceptions. }\end{array}$ \\
\hline & Ecological section \\
\hline Indicators & Benefits \\
\hline $\begin{array}{l}\text { Existence of protected areas } \\
\text { in the destination }\end{array}$ & $\begin{array}{c}\text { Measuring the potential need to protect sensitive and } \\
\text { essential habitats. }\end{array}$ \\
\hline $\begin{array}{l}\text { Water consumption (11 per } \\
\text { tourist) }\end{array}$ & $\begin{array}{l}\text { The indicator can indicate possible limits or stress impacts } \\
\text { on water supplies. }\end{array}$ \\
\hline $\begin{array}{l}\text { The volume of waste } \\
\text { generated at the destination } \\
\text { per month }\end{array}$ & $\begin{array}{l}\text { One of the features of sustainable tourism is an effort to } \\
\text { reduce waste production or recycling. }\end{array}$ \\
\hline $\begin{array}{l}\text { Energy consumption } \\
\text { (renewable and non- } \\
\text { renewable sources) }\end{array}$ & $\begin{array}{l}\text { The aim is to promote the use of energy from renewable } \\
\text { sources. }\end{array}$ \\
\hline $\begin{array}{l}\% \text { of ecologically oriented } \\
\text { enterprises }\end{array}$ & $\begin{array}{l}\text { Minimizing the adverse effects of any organization's } \\
\text { activities contributes to destination sustainability. }\end{array}$ \\
\hline
\end{tabular}


Once the destination decides to focus on monitoring sustainability using indicators, it is necessary to create a responsible group of people. These people are intended to define the goal, reach it regularly and monitor the indicators of tourism sustainability. This group should, in particular, include those organizations and individuals who are directly or indirectly involved in the tourism operation of a particular destination and have a decisive role in the management of the destination, such as local authorities, water and energy suppliers, tourist organizations, accommodation and catering facilities, landfill operators, etc. This solution enables a more efficient collection of information, better communication between participants, but also faster implementation of the necessary measures. These groups must initially set out a strategy to follow and identify needs and problem areas in the destination. There is also a need to set priority indicators, a precise timetable for data collection and the corresponding responsibilities - who should deal with what information and collect data according to its relevance. Measuring and monitoring sustainability using indicators requires setting time intervals for data recovery and determining the exact locations with high tourism activity. The determination of time indicators depends on their nature. The measurement of key indicators should be done annually; additional indicators can be measured depending on the frequency of change of their values. The indicators cover the essential aspects of sustainability and create the basis for effective destination management. Additional indicators are not mandatory; they serve to expand monitoring and support sustainability in specific tourism activities in a particular destination. It is crucial to analyse the results of the data collected so far. Based on the analysis, it is possible to decide on the follow-up measures and objectives related to the sustainability of tourism in a particular destination.

\section{Conclusion}

The world nowadays faces the topics not only in the context of globalization as its already integral part but also due to sustainability in its various directions and areas of operation. Development, whether in society or terms of technology, is continuously advancing. The effects of globalization are multispectral. We can monitor the interconnection of several areas and the spreading information at high speed daily. As the globalized world moves at extremely high pacing and people have become used to it over time, organizations and the public need to start working on sustainability. In terms of tourism and the associated regional development, it is necessary to develop such activities that would help not only their future existence but also the future generation in general. The constant rush of individuals and organizations to be active and do something has a negative side effect on their surroundings in various areas. Over time, the negative impact may also affect the prosperity and comprehensive development of the region. In this article, we aimed to point out the positive impact of the use of sustainable tourism indicators for the development of the Trenčín region as part of our analysis. The nature and predisposition of the Trenčín region, according to the analysed available sources, point to the insufficient use of the concept of sustainable tourism. We, therefore, propose the introduction of the mentioned indicators of sustainable tourism in three areas, in particular economic, socio-cultural and ecological one. The indicators will help the region to develop and subsequently improve the current situation comprehensively. Also, through the indicators, positive reactions from the general public, as well as visitors towards the destination, are expected. It can ultimately cause more significant interest in visiting the region and also higher competitiveness among other regions in Slovakia. 
This paper is an output of the research project supported by the Grant Agency of the Ministry of Education of the Slovak Republic and the Slovak Academy of Sciences (VEGA) No. 1/0078/18 titled Aspects of Marketing Communication in the Management Processes of Circular Economy.

\section{References}

1. Gajdoš, P. (2009). Globalizačné súvislosti urbánneho vývoja a jeho sociálnopriestorové špecifiká. Sociológia, 41(4), 304-328.

2. Kurekova, L., Hejdukova, P. (2016). Globalization and migration: the empirical study of panel data of the migration in the Czech Republic and the Slovak Republic. In T. Kliestik (Ed.), Proceedings of the 15th International Scientific Conference on Globalization and its Socio-Economic Consequences (pp. 1136-1144). Rajecké Teplice, Slovakia.

3. Skorska, A., Balcerowicz-Szkutnik, M., Wąsowicz, J. (2016). Globalization as the determinant of high-tech sector development. In T. Kliestik (Ed.), Proceedings of 16th International Scientific Conference Globalization and Its Socio-Economic Consequences (pp. 2028-2036). Rajecke Teplice, Slovakia.

4. Antras, P., De Gortari, A., Itskhoki, O. (2017). Globalization, inequality and welfare. Journal of International Economics, 108, 387-412.

5. Bednárik, J. (2018). Circular economy as a prerequisite of sustainable development in the global environment. In T. Kliestik (Ed.), Proceedings of the 18th International Scientific Conference on Globalization and its Socio-Economic Consequences (pp. 986-993). Rajecké Teplice, Slovakia.

6. Wróblewski, Ł., Dacko-Pikiewicz, Z., Cuyler, A. C. (2017). The European Union consumer behaviour in the festivals market in Poland. Polish Journal of Management Studies, 16(2), 302-314.

7. Valli, V., Saccone, D. (2015). Structural Change, Globalization and Economic Growth in China and India. European Journal of Comparative Economics, 12(2), 133- 163.

8. Kurowska-Pysz, J., Szczepańska-Woszczyna, K., Štverková, H., Kašík, J. (2018). The catalysts of cross-border cooperation development in Euroregions. Polish Journal of Management Studies, 18(1), 180-193.

9. Burlacu, S., Gutu, C., Matei, F. O. (2018). Globalization-pros and cons. Calitatea, 19(1), 122-125.

10. Gennaioli, N., La Porta R., Lopez-de-Silanes, F., Schleifer, A. (2013). Human Capital and Regional Development. The Quarterly Journal of Economics, 128(1), 105-164.

11. Delogu, M., Docquier, F., Machado J. (2018). Globalizing labor and the world economy: the role of human capital. Journal of Economic Growth, 23(2), 221- 226.

12. Bednárik, J., Čapkovičová, B. (2015). Media and business crisis communication in the time of crisis. In T. Kliestik (Ed.), Proceedings of the 15th International Scientific Conference on Globalization and its Socio-Economic Consequences (pp. 13-18). Rajecké Teplice, Slovakia.

13. Ginevicius, R., Gedvilaite, D., Stasiukynas A. (2018). Impact of Economic Development on the Ecology in the Regions of Lithuania. E\&M Economics and Management, 21(2), 21-37.

14. Morvay, K., Okali, I. Gabrielova, H., Hvozdikova, V., Sikulova, I., Frank, K., Jeck, T. (2013). Economic Development of Slovakia in 2012 and Outlook up to 2014. Ekonomický časopis, 61(8), 767-845. 
15. Regnerova, O., Regnerova, M. (2017). Sustainable development in "the light and shadow" of globalization. Ekonomicko-manazerske spectrum, 11(1), 2-12.

16. Horner, R., Schindler, S., Haberly, D. et al. (2018). Globalization, uneven development and the North-South' big switch'. Cambridge Journal of Regions Economy and society, 11, 17-33.

17. UNWTO (2004). Indicators of sustainable development for tourism destinations: A guidebook. Madrid: World Tourism Organization.

18. OECD (2005). Measuring Globalisation. OECD Handbook on Economic Globalisation Indicators. OECD, France.

19. DG Enterprise and Industry (2020, July 29). European tourism indicator system Toolkit for sustainable destinations. EU Indicator toolkit. Retrieved from : https://ceetonetwork.eu/content/ec_european_tourism_indicator_system_toolkit_for_su stainable_destinations_2013.pdf

20. Trenčín.sk (2020, July 28). About Trenčín. Retrieved from : https://trencin.sk/ 